\title{
Eating Disorders in Developing Countries
}

\author{
Suprakash Chaudhury* and Swaleha Mujawar \\ Department of Psychiatry, Dr. DY Patil Medical College, India
}

*Corresponding author: Suprakash Chaudhury, Department of Psychiatry, Dr. DY Patil Medical College, India

\section{Editorial}

Eating disorders, once thought to be a set of rare diseases, found predominantly in females, are being increasingly seen in both males and females. They include binge eating disorder (BED), anorexia nervosa ( $\mathrm{AN})$, bulimia nervosa (BN), pica, rumination disorder, avoidant/restrictive food intake disorder, and a group of other specified feeding or eating disorders [1]. Eating disorders occur predominantly in females and the onset often follows puberty [2].

The number of people coming to psychiatrists with problems of anorexia and bulimia has shown a steady rise. It has been estimated that the lifetime prevalence of DSM-IV anorexia nervosa, bulimia nervosa, and binge eating disorder are $0.9 \%, 1.5 \%$, and $3.5 \%$ among women, and $0.3 \% 0.5 \%$, and $2.0 \%$ among men in USA [3]. In Ontario prevalence rates of of BN was $1.1 \%$ in women and $0.1 \%$ in men [4]. The prevalence rates for AN and BN in Zurich was $0.7 \%$ and $0.5 \%$ respectively [5]. In South Australia the prevalence of BN and BED was $0.3 \%$ and $1 \%$ respectively [6]. Across six European countries the prevalence rates for $\mathrm{AN}, \mathrm{BN}$, and BED were $0.48 \%$, $0.51 \%$, and $1.12 \%$ respectively [7]. Eating disorders as a group are psychiatric disorders with the highest mortality rate, resulting in about 7,000 deaths a year in 2010 [8]. What was earlier thought as a disease pertaining to a few developed countries is now being increasingly seen in developing countries. Moreover, patients of all ages and sexes are coming with these problems.

This has been attributed to acculturation and exposure through the media to Western standards of attractiveness and body size [2,9]. Increasingly, the population of developing countries is adopting Western views on thinness and the dietary habits associated with that state [9]. The point prevalence of $\mathrm{AN}, \mathrm{BN}$ and BED in China and Japan is 1.05 and $0.43 ; 2.98$ and 2.32; and 3.58 and 3.32 respectively [10]. The prevalence of eating disorder is believed to have increased in India over the past three decades as indicated by sporadic case reports. [11-12]. Though no epidemiological studies have been carried out using the Global Burden of Disease Study 2016 approach it was estimated that the prevalence rate of
AN for males was 10/100,000, whereas for females, it was 37.2 and combined prevalence was $22.3 / 100,000[13]$.

The cause of eating disorders is not very clear as it is seen that biological and environmental factors appear to play a role. Many studies have shown a possible genetic predisposition causing eating disorders due to Mendelian inheritance [14]. A role for serotonin 4 receptors has been proposed [15]. Some studies suggest that both early pubertal timing and advanced pubertal development in girls are associated with increased rates of eating disorders. On the other hand, findings in boys suggest a smaller role for puberty in the development of eating disorders. Results from twin and animal studies suggest that the female-specific risk is due, at least partly, to genetic factors associated with puberty related estrogen activation [16]. People having previous disorders like anxiety, obsessive compulsive disorder etc have increased vulnerability to developing an eating disorder [17-18]. Cultural idealization that beauty is the same as thinness is also believed to contribute to the etiology [19]. Self-respect is being linked to the body shape and size. Social change and globalization are causing the shift in the thinking of the people in urban cities.

The children are being exposed to social media these days. A significant link has been shown between self-objectification, body dissatisfaction, and disordered eating, as the beauty ideal is altered through social media [20]. Organic cause and other psychiatric disorders must be ruled out before diagnosing eating disorder. The test to be done should include neuroimaging [21]. Beck Depression Inventory [22] just to name a few. Treatment differs according to type and severity of eating disorder, and more than one treatment option is used [23]. Treatment includes pharmacotherapy and psychotherapy. Medicines which can be given are cyproheptidine, [24] pimozide [25] and zinc supplementation [26] for anorexia nervosa, naltrexone for binge eating [27]. Cognitive behavioral therapy, [28] Dialectical behavior therapy [29] family therapy [30] are some of the therapies which show promising results. Most of the patients and their families do not know that they are 
suffering from a psychiatric disorder and may go to physicians for physical complaints. They are very reluctant and rarely come to psychiatrists. Patients should be encouraged to seek psychiatric treatment through media and other social awareness programmes.

\section{References}

1. (2013) American Psychiatry Association. Diagnostic and Statistical Manual of Mental Disorders ( $5^{\text {th }}$ ed.); American Psychiatric Publishing, Arlington, USA, 329-354

2. Schmidt U (2003) Aetiology of eating disorders in the $21^{\text {st }}$ century: new answers to old questions. European Child \& Adolesc Psychiatry 12(Suppl1): 130-137.

3. Hudson J, Hiripi E, Pope H, Kessler R (2007) The Prevalence and Correlates of Eating Disorders in the National Comorbidity Replication. Biol Psychiatry 61(3): 348-358.

4. Garfinkel PE, Lin E, Goering P, Spegg C, et al. (1995) Bulimia Nervosa in a Canadian community sample: Prevalence and comparison of subgroups. Am J Psychiatry 152(7): 1052-1058

5. Steinhausen HC, Winkler C, Meier M (1997) Eating disorders in adolescence in a Swiss epidemiological study. Int J Eat Disord 22(2):147151.

6. Hay P (1998) The epidemiology of eating disorder behaviors: An Australian community based survey. Int J Eat Disord 23(4): 371-382.

7. Preti A, Girolamo Gd, Vilagut G, Alonso J, Graaf Rd, et al. (2009) The epidemiology of eating disorders in six European countries: Results of the ESEMeD-WMH project. J Psychiatr Res 43(14): 1125-1132.

8. Lozano R, Naghavi M, Foreman K, Lim S, Shibuya K, et al. (2012) Global and regional mortality from 235 causes of death for 20 age groups in 1990 and 2010: A systematic analysis for the Global Burden of Disease Study 2010. Lancet 380(9859): 2095-2128.

9. Bhugra D, Mastrogianni A, Maharajh H, Harvey S (2003) Prevalence of bulimic behaviours and eating attitudes in schoolgirls from Trinidad and Barbados. Transcult Psychiatry 40(3): 409-428.

10. Hoek HW (2016) Review of the worldwide epidemiology of eating disorders. Curr Opin Psychiatry 29(6): 336-339.

11. Chaudhury S, John TR (2001) Anorexia Nervosa. Indian J Psychiatry 43(3): 264-266.

12. Pani A, Santra G, Biswas KD (2015) Anorexia Nervosa with ObsessiveCompulsive Disorder. JAPI 63(9): 82-83.

13. Mohandoss AA (2018) A study of burden of anorexia nervosa in India -2016. J Mental Health Hum Behav 23: 25-32.

14. Mazzeo SE, Bulik CM (2009) Environmental and genetic risk factors for eating disorders: What the clinician needs to know. Child Adolesc Psychiatr Clin North Am 18(1): 67-82.
15. Compan V (2017) Serotonin 4 Receptors: A Cornerstone in Anorexia Nervosa? Autism Open Access 7(2): 201-207.

16. Klump KL (2013) Puberty as a Critical Risk Period for Eating Disorders: A Review of Human and Animal Studies. Horm Behav 64(2): 399-410.

17. Kaye WH, Bulik CM, Thornton L, Barbarich N, Masters K (2004) Comorbidity of anxiety disorders with anorexia and bulimia nervosa. Am J Psychiatry 161 (12): 2215-2221.

18. Thornton C, Russell J (1997) Obsessive compulsive comorbidity in the dieting disorders. Int J Eat Disord 21(1): 83-87.

19. Rikani AA, Choudhry Z, Choudhry AM, Ikram H, Asghar MW, et al. (2013) A critique of the literature on etiology of eating disorders. Ann Neurosci 20(4): 157-161.

20. Ghaznavi J, Taylor LD (2015) Bones, body parts, and sex appeal: An analysis of \#thinspiration images on popular social media. Body Image 14: 54-61.

21. O’Brien A, Hugo P, Stapleton S, Lask B (2001) Anorexia saved my life: coincidental anorexia nervosa and cerebral meningioma. Int J Eat Disord $30(3): 346-349$

22. Kennedy SH, Kaplan AS, Garfinkel PE, Rockert W (1994) Depression in anorexia nervosa and bulimia nervosa: Discriminating depressive symptoms and episodes. J Psychosom Res 38(7): 773-782.

23. Halmi KA (2005) The multimodal treatment of eating disorders. World Psychiatry 4(2): 69-73.

24. Goldberg SC, Halmi KA, Eckert ED, Casper RC, Davis JM (1979) Cyproheptadine in anorexia nervosa. Br J Psychiatry 134: 67-70.

25. Vandereycken W, Pierloot R (1982) Pimozide combined with behavior therapy in the short-term treatment of anorexia nervosa. A double-blind placebo-controlled cross-over study. Acta Psychiatr Scand 66 (6): 445450 .

26. Birmingham CL, Gritzner S (2006) How does zinc supplementation benefit anorexia nervosa?. Eating and weight disorders 11 (4): 109-111.

27. Marrazzi MA, Markham KM, Kinzie J, Luby ED (1995) Binge eating disorder: Response to naltrexone. International Journal of Obesity and related metabolic disorders 19(2): 143-145.

28. Pike KM, Walsh BT, Vitousek K, Wilson GT, Bauer J (2003) Cognitive behavior therapy in the posthospitalization treatment of anorexia nervosa. Am J Psychiatry 160(11): 2046-2049.

29. Salbach Andrae H, Bohnekamp I, Pfeiffer E, Lehmkuhl U, Miller AL (2008) Dialectical behavior therapy of anorexia and bulimia nervosa among adolescents: A case series. Cog behav Pract 15(4): 415-425.

30. Eisler I, Dare C, Hodes M. Russell G (2000) Family therapy for adolescent anorexia nervosa: The results of a controlled comparison of two family interventions J Child Psychol Psychiatry 41(6): 727-736.
To Submit Your Article Click Here: This work is licensed under Creative Commons Attribution 4.0 License

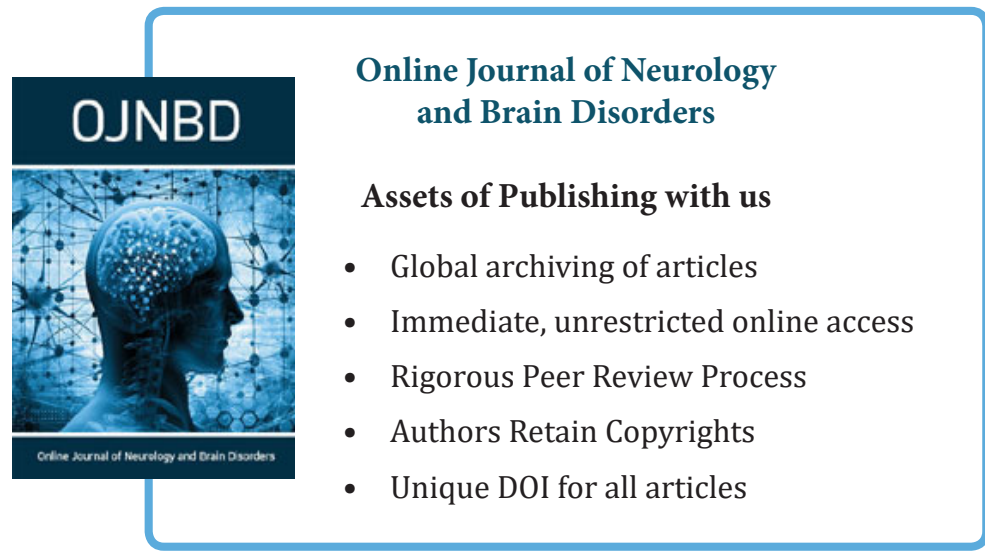

